\title{
Antecedents of Employee Burnout in the Oil and Gas Industry
}

Ahmad Nizan Mat Noor, Eliy Nazira Mat Nazir, Shaiful Annuar Khalid, Zulaiha Ahmad, Izzati Husna Muhamad Rizal

To Link this Article: http://dx.doi.org/10.6007/IJARBSS/v11-i9/10921

DOI:10.6007/IJARBSS/v11-i9/10921

Received: 20 July 2021, Revised: 22 August 2021, Accepted: 12 September 2021

Published Online: 25 September 2021

In-Text Citation: (Noor et al., 2021)

To Cite this Article: Noor, A. N. M., Nazir, E. N. M., Khalid, S. A., Ahmad, Z., \& Rizal, I. H. M. (2021). Antecedents of Employee Burnout in the Oil and Gas Industry. International Journal of Academic Research in Business and Social Sciences, 11(9), 1856-1865.

Copyright: (c) 2021 The Author(s)

Published by Human Resource Management Academic Research Society (www.hrmars.com)

This article is published under the Creative Commons Attribution (CC BY 4.0) license. Anyone may reproduce, distribute, translate and create derivative works of this article (for both commercial and non-commercial purposes), subject to full attribution to the original publication and authors. The full terms of this license may be seen at: http://creativecommons.org/licences/by/4.0/legalcode

Vol. 11, No. 9, 2021, Pg. 1856 - 1865

Full Terms \& Conditions of access and use can be found at http://hrmars.com/index.php/pages/detail/publication-ethics 


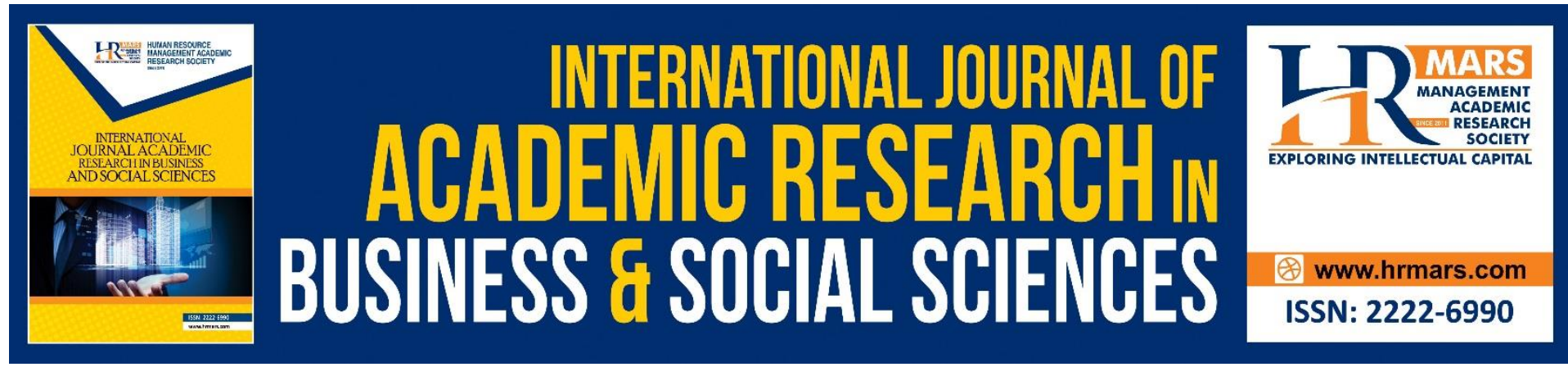

\title{
Antecedents of Employee Burnout in the Oil and Gas Industry
}

\author{
Ahmad Nizan Mat Noor, Eliy Nazira Mat Nazir, Shaiful Annuar \\ Khalid, Zulaiha Ahmad, Izzati Husna Muhamad Rizal
}

Faculty of Business and Management, Universiti Teknologi MARA Perlis Branch, Malaysia Email: ahmadnizan@uitm.edu.my

\begin{abstract}
The purpose of this study was to look at the factors that impact job burnout among Malaysian oil and gas employees. Workplace bullying, organizational change, and work-family conflict are the predictor variables included in this research study. In this study, quantitative approaches were used, and data was collected via distributed questionnaires. The statistical Package for the Social Sciences (SPSS) software version 23.0 was then used to analyze the data. Several analyses, including correlations and multiple regression analyses, were also carried out. Certain variables appear to have a major impact on job burnout, according to the findings. The results of the study can be utilized by the company to improve its practices aimed at reducing job burnout among employees, thereby increasing employee performance. Keywords: Job Burnout, Workplace Bullying, Organizational Change, Work-Family Conflict
\end{abstract}

\section{Introduction}

Job burnout is a persistent affective condition associated with work and slowly increasing over time as a result of constant stress at work. Job burnout basically happens when someone feels emotionally drained, overwhelmed and incapable of meeting constant demands (Freudenberger, 1974). As results, this situation affected someone's motivation and interest in performing certain roles. Moreover, burnout at the workplace itself can also lessen employee's productivity and affect their performances. Earlier studies have reported various factors that can contribute to job burnout such as stressor at the workplace (Khamisa et al., 2015), workplace bullying (Srivastava and Dey 2019), lack of resources (Puleo, 2011), raise the time constraint (Rabatin et al., 2015), work-family conflicts (Guangdong Wu et al., 2018), organizational change (Day et al., 2017) and loss of job control or a reduction in autonomy (Leiter and Maslach, 2009). Therefore, job burnout has caused workers to lose interest in work, absenteeism, desire to quit or real turnover, experience dissatisfaction and a sense of frustration that prevents workers from carrying out their task in a good manner (Najam et al., 2018). Job burnout can be seen as a very serious problem that an organization has ever faced. Accordingly, identifying factors contributing to those issues and maintaining the productivity of employees in a company was very important nowadays. Hence, the main aim of this research is to investigate the extent to which workplace bullying, organizational change and 
work-family conflict influence job burnout. Hopefully, this study will provide a better insight for the employers to deal with job burnout.

\section{Literature Review Job Burnout}

Freudenberger first presented the concept of job burnout more than 40 years ago (1974). Burnout, according to Freudenberger, occurs when a worker becomes psychologically exhausted and worn out as a result of excessive work expectations. Burnout, according to Maslach and Jackson (1981), has three dimensions: emotional tiredness, depersonalization, and a diminished sense of personal accomplishment from the job. In general, there is a widespread belief that burnout is caused by work issues and then by personality variables (Bianchi, 2018; Maslach, 2003, 2006; Shanafelt et al., 2017). Job burnout has been linked to a variety of negative workplace consequences. Burnout, for example, was once thought to be a predictor of absenteeism (Bakker et al., 2003; Borritz et al., 2006), turnover (Maslach, 2006; Maslach and Leiter, 2016; Wright and Cropanzano, 1998), job attitudes (Moore, 2000), and job performance (Halbesleben and Buckley, 2004; Keijsers et al. 1995; Wright and Bonnet, 1997). In conclusion, job burnout is one of the most critical issues that a firm has ever encountered. As a result, understanding variables that contribute to these challenges and preserving employee productivity in an organization is critical nowadays.

\section{Workplace Bullying}

Lately, workplace bullying has gained substantial attention from scholars and practitioners (Eisele, 2016; Naseer and Khan, 2015). Workplace bullying can be understood as the frequent, persistent and systematic display of violent, unreasonable behavior and negative attitudes towards people at work (Ciby and Raya, 2015; Naseer and Khan, 2015; Yuen and Han, 2016). According to Rai and Agarwal (2017), workplace bullying may occur through unnecessary deadline, biased workloads, practical jokes, spreading rumors, violent remarks, targetoriented intimidations and endless work surveillance. All of these acts can be divided into two categories: workplace bullying and personal bullying (Yahaya et al., 2012). Furthermore, such abuse and harassment of the individual may be an indication to the victim that may end up in a position of inferiority and unable to protect himself or herself (Rai and Agarwal, 2017).

\section{Organizational Change}

Organizational change as proposed by scholars is related to the wide-ranging organizational change that may include project reform, transforming processes, fusions and partnership among others, which requires transformation of the organization (Kotter and Schlesinger, 2008). Furthermore, organizational change occurs when an organization transitions from its current state to its ideal future state. Organizational transformation, according to Anderson (2013), is critical to working life and necessitates adjustments at both the organizational and human levels.

\section{Work-family conflict}

Work-family conflict is characterized by Greenhaus and Beutell (1985) as inter-role conflict resulting from unbalanced tensions between work and family roles. Work-life conflict is a subset of work-family conflict, and it refers to the fact that the role of work can conflict with other individual responsibilities and preferences. Aside from family responsibilities, these can include time with peers, a workout, serving in the military, education, time for self-care and 
recovery, volunteering or engagement in religious organizations. Although work-family conflict continues to be an important component for many workers, scholars sometimes misinterpret all types of non-work-related conflict within the work-family measure, both methodologically and philosophically (Wilson and Baumann, 2015). As a result, some scholars, such as Siegel et al. (2005), used the term work-life disagreement to characterize the many other non-work requirements in the lives of individuals that aren't confined to those affecting their families.

\section{Relationship between Workplace Bullying and Employee's Job Burnout}

Employees exposed to bullying in the workplace, according to Yeun and Han (2016), encounter work-related stress, which correlates to an advanced prevalence of job burnout. Employees who have been subjected to workplace abuse may experience long-term stress or depression. It can lead to worker burnout due to feelings of inadequacy or lack of selfconfidence, which can lead to absenteeism and turnover. Najam et al. (2018) supported this. They found that bullying at the workplace causes workers to encounter burnout. Similarly, Yildiz (2015) discovered a link between workplace bullying and characteristics of burnout, specifically emotional and physical tiredness. Furthermore, Allen et al. (2015) found that workplace bullying causes an increase in burnout feelings among workers, especially when seniority is involved. Bullying in the workplace, according to Naseer et al., (2016), drains a person and eventually leads to work burnout and psychological strain. They went on to say that workplace bullying saps an employee's energy and, as a result, leads to job burnout. Hence, the hypothesis posits:

H1: Workplace bullying has a positive relationship with job burnout.

\section{Relationship between Organizational Change and Employee's Job Burnout}

Changes in organization, according to Day et al. (2017), are one of the factors that contribute to job burnout. Organizational transformation has become a necessary part of working life, necessitating adjustments not only at the organizational level but also at the individual level of employees (Anderson, 2013). In terms of organizational reform, it is about organizations undergoing rapid change, and worker safety and well-being has emerged as a major subject. Employees may experience psychological and physical stress as a result of organizational change (Hylton, 2004). Although positive organizational services like supporting and task management can help workers avoid burnout, researchers have agreed that organizational change is one of the causes of workplace burnout (Dubois et al., 2014; Puleo, 2011). As a result, the detrimental impact of organizational transition on workers' work lives and psychological well-being is not a new phenomenon (Bourbonnais et al., 2005; Greenglass et al., 2002). Moreover, employee mental concern about how the shift will have an impact on their lives is sometimes linked to changes within the company (Rafferty and Griffin, 2006). Hence, the hypothesis posits:

$\mathrm{H}$ 2: Organizational change has a positive relationship with job burnout.

\section{Relationship between Work-Family Conflict and Employee's Job Burnout}

Greenhaus and Beutell (1985) conceptualized work-family conflict based on the source of conflict. In other words, work-family conflict is a sort of conflict involving the roles of family and work. Conflicts of work and family can therefore be separated into two categories: 
conflict of work and family work. The former relates to encroachment and interference at home, while the former refers to interference at work and at home (Frye and Breaugh, 2004). When work interferes with their families, workers are more likely to consider quitting their jobs. According to Anderson et al. (2002), work-family conflict affects job satisfaction, work stress, and turnover intention, whereas family-work conflict affects work tension and absenteeism. Furthermore, conflict between work and family is one of the causes of job burnout, and it most commonly affects employees, disrupting their work and family time. Increased work-family conflict results in greater job burnout, which results in inferior organizational and individual performance (Guangdong Wu et al., 2018). The following hypothesis is proposed based on the preceding discussion:

H3: Work-family conflict has a positive relationship with job burnout.

\section{Research Methodology}

In order to determine the antecedents of employees' job burnout, this study used a quantitative research approach. In the current study, data was gathered from a group of respondents via questionnaires. We employed a structured Likert-type scale spanning from strongly disagree (1) to strongly agree (5) and respondents' demographic profile being also collected. As independent factors, workplace bullying, organizational change, and workfamily conflict were used to assess the impact on an employee's job burnout. The data was analyzed using SPSS software version 23.0 to determine the relationship between the variables.

\section{Findings}

The study's major goal was to look into the role of workplace bullying, organizational change, and work-family conflict as precursors to employee burnout. The association between variables was verified using correlation and multiple regression analysis tests. Results of multiple regression was used to test the study hypotheses.

\section{Correlation Analysis}

According to Table 1 , there is a ( $r=.566)$ positive correlation between workplace bullying and job burnout, showing that there is a strong positive correlation and that it is statistically significant at the level of $(p=.000)$. This finding demonstrated that workplace bullying has an impact on job burnout. Furthermore, there is a positive link $(r=.454)$ between organizational change and job burnout, according to this study. The result also indicates a moderate positive connection, which is statistically significant at the level of $(p=.000)$, indicating that there is a statistically significant positive link between organizational change and employee job burnout. Finally, the findings revealed a $(r=.480)$ positive association between work-family conflict and employee job burnout. Work-family conflict and employee job burnout have a moderate positive association that is statistically significant at the level of $(p=.000)$, indicating that there is a statistically significant positive link between the two. Correlational analysis provides initial support for the study hypotheses. 
Table 1. Results of Pearson's Correlation Analysis

\begin{tabular}{lllll}
\hline & $\begin{array}{l}\text { Workplace } \\
\text { Bullying }\end{array}$ & $\begin{array}{l}\text { Org. } \\
\text { Change }\end{array}$ & $\begin{array}{l}\text { Work Family } \\
\text { Conflict }\end{array}$ & Job Burnout \\
\hline Workplace Bullying & 1 & & & \\
Org. Change & $.753^{* *}$ & 1 & & \\
Work Family Conflict & $.451^{* *}$ & $.604^{* *}$ & 1 & \\
Job Burnout & $.566^{* *}$ & $.454^{* *}$ & $.480^{* *}$ & 1 \\
\hline
\end{tabular}

${ }^{*} p<.05 * * p<.01$

\section{Multiple Regression Analysis}

This analysis was utilized in this study to look into the relationship between job burnout as a response variable and the independent variables. Standardized Coefficient Beta, Significant, and $\mathrm{R}$ square were used to check the assumption of multiple regressions and ensure that the outputs were appropriate.

\section{Model Fit}

The model summary of R-value as a level of prediction of the dependent variable is shown in Table 2 below. The outcome of this study indicated that the level of prediction for this model is acceptable. The $\mathrm{R}$ square value of 0.390 indicates that the independent and dependent variables explained 39.0 percent of the variability in the dependent variable.

Table 2. Model Summary of Multiple Regression Analysis

\begin{tabular}{lllll}
\hline Model & R Square & $\begin{array}{l}\text { Adjusted } \\
\text { R Square }\end{array}$ & $\begin{array}{l}\text { Std. Error of the } \\
\text { Estimate }\end{array}$ & \\
\hline $1.624 \mathrm{a}$ & .390 & .370 & 5.73260 & \\
\hline
\end{tabular}

\section{Statistical Analysis}

The total regression was investigated using ANOVA to see if the model is a significant predictor of the result variable. $F(1,980)=19.796, p=0.01$ suggested that the model was a significant predictor of job burnout (Table 3).

Table 3. Model Summary of ANOVA

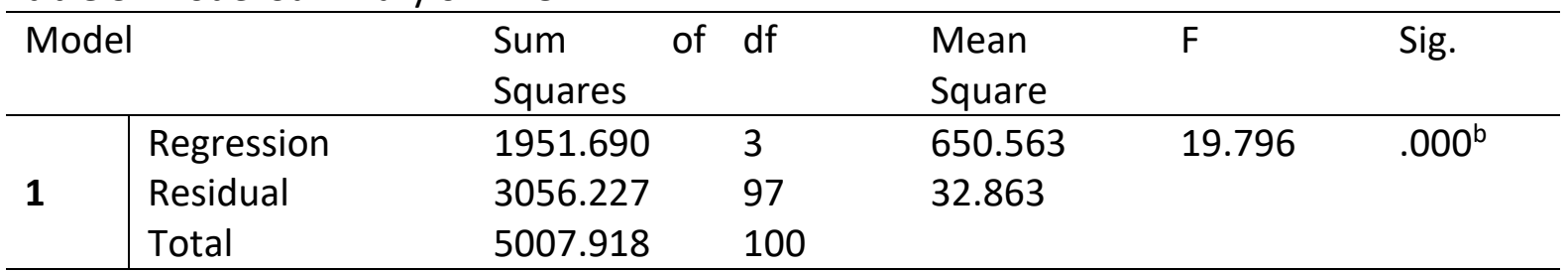

a. Dependent Variable: meanJB

b. Predictors: (Constant), meanWB, meanOC, meanWFC

\section{Estimated Model Coefficient}

The unstandardized coefficient for workplace bullying is 0.466 , which suggests that for every rise in workplace bullying, there is a 0.466 -level increase in employee job burnout. The equation $Y=0.466 x+C$ characterizes this. The significant value of $p=0.00$ was also discovered, indicating that workplace bullying has a significant impact that adds to the model. The unstandardized coefficient for organizational change is -0.170 , which suggests that for every 0.170 increase in organizational change, there is a 0.170 decrease in employee work burnout. 
The equation $Y=-0.170 x+C$ represents this. The significance of $p=0$ is also shown in the result. The significant value of $p=0.332$ in the result also indicates that organizational change is not a substantial contributor to the model. Finally, the unstandardized coefficient for work-family conflict is 0.309 , indicating a one-level rise in work-family conflict and a 0.309 -level increase in employee job burnout. The equation $Y=0.309 x+C$ represents this. Work-family conflict is a significant factor that adds to the model, as evidenced by the substantial value of $p=0.00$.

\section{Statistical Significant of Independent Variables}

The result of workplace bullying is $p=0.00$, according to Table 4 . It is clear that workplace bullying is linked to employee job burnout in a major way. Meanwhile, organizational change reveals that the result is $p=0.332$ and has a negligible relationship with employee job burnout. The outcome of work-family conflict, on the other hand, is $p=0.00$, indicating that work-family conflict is significantly linked to employee job burnout. Based on the result of multiple regression, $\mathrm{H} 1$ and $\mathrm{H} 3$ are supported, whereas $\mathrm{H} 2$ is rejected.

Table 4. Coefficient Value of the Variables

\begin{tabular}{l|lllllll}
\hline Model & \multicolumn{3}{l}{$\begin{array}{l}\text { Unstandardized } \\
\text { Coefficients }\end{array}$} & $\begin{array}{l}\text { Standardized } \\
\text { Coefficients }\end{array}$ & t & Sig. \\
\cline { 3 - 8 } \multicolumn{2}{c}{} & B & Std. Error & Beta & & \\
\hline \multirow{3}{*}{1} & (Constant) & 10.974 & 2.765 & & 3.970 & \\
& MeanWB & .466 & .111 & .519 & 4.219 & .000 \\
& MeanOC & -.170 & .174 & -.134 & -.975 & .332 \\
& MeanWFC & .309 & .096 & .327 & 3.218 & .000 \\
\hline
\end{tabular}

a. Dependent Variable: meanJB

\section{Conclusion}

The objective this study was to examine the effect of workplace bullying, organizational change, and work-family conflict on job burnout. Of the three predictors, only organizational change was not a significant predictor of job burnout. This study shed light on the elements that contribute to employee job burnout in the oil and gas industry. Workplace bullying, organizational change, and work-family conflict are among the predicted variables. Furthermore, regression analysis proved very effective in determining the model's overall fit. Future research in this area, on the other hand, may provide a wonderful notion for formulating, examining, and establishing a strong research model that can provide better knowledge of the components that contribute to employee job burnout. This is because a variety of issues, such as insufficient resources (Puleo, 2011), time constraint (Rabatin et al., 2015), ambiguity or conflict in one's role (Kilfedder et al., 2001), a reduction in autonomy or a loss of job control, all contribute to employee job burnout (Leiter and Maslach, 2009). Furthermore, knowing the causes of burnout in the workplace is critical for valuing employees' attitudes regarding their workplaces.

\section{References}

Allen, B. C., Holland, P., \& Reynolds, R. (2015). The effect of bullying on burnout in nurses: the moderating role of psychological detachment. J Adv Nurs, 71(2), 381-90.

Anderson, D. L. (2013). Organization Development: The Process of Leading Organizational Change. Sage Publications. 
Anderson, S. E., Coffey, B. S., \& Byerly, R. T. (2002). Formal organizational initiatives and informal workplace practices: Links to work-family conflict and job-related outcomes. Journal of Management, 28(6), 787-810.

Bakker, A. B., Demerouti, E., De Boer, E., \& Schaufeli, W. B. (2003). Job demands and job resources as predictors of absence duration and frequency. Vocational Behavior, 62(2), 341-356.

Bianchi, R. (2018), Burnout is more strongly linked to neuroticism than to work-contextualized factors. Psychiatry Research, 270, 901-905.

Borritz, M., Rugulies, R., Christensen, K. B., Villadsen, E., \& Kristensen, T. S. (2006). Burnout as a predictor of self-reported sickness absence among human service workers: Prospective findings from three year follow up of the PUMA study. Occupational and Environmental Medicine, 63(3), 98-107.

Bourbonnais, R., Brisson, C., Malenfaut, R., \& Vezina, M., (2005). Health care restructuring, work environment, health of nurses. Am. J. Ind. Med. 47 (1), 54-64.

Ciby, M., \& Raya, R. P. (2015). Workplace bullying: A review of the defining features, measurement methods and prevalence across continents. Society \& Management Review, 4 (1), 38-47.

Dubois, C. A., Bentein, K., Mansour, J. B., Gilbert, F., \& Bedard, J. L. (2014). Why some employees adopt or resist reorganization of work practices in health care: associations between perceived loss of resources, burnout, and attitudes to change. Int. J. Environ. Res. Public Health, 11 (1), 187-201.

Eisele, P. (2016). Organizational justice and workplace bullying: validating two instruments and testing their joined relation with wellbeing. International Journal of Business and Social Science, 7(12), 167-176.

Freudenberger, H. J. (1974). Staff burn-out. Journal of social issues, 30(1), 159-165.

Frye, N. K., \& Breaugh, J. A. (2004). Family-friendly policies, supervisor support, work-family conflict, family-work conflict, and satisfaction: A test of a conceptual model. Journal of Business and Psychology, 19(2), 197-220.

Greenglass, E. R., Burke, R. J., \& Moore, K. A. (2002). Reactions to increased workload: effects on professional efficacy of nurses. Appl. Psychol.: Int. Rev, 52, 580-597.

Greenhaus, J. H., \& Beutell, N. J. (1985). Sources of conflict between work and family roles. Academy of Management Review, 10, 76-88.

Halbesleben, J. R. B., \& Buckley, M. R. (2004), Burnout in organizational life. Management, 30 (6), 859-879.

Hylton, J. (2004). Leadership: the next HHR crisis? Health Care Manage. Forum, 17 (2), 3-4.

Keijsers, G. J., Schaufeli, W. B., Le Blanc, P. M., Zwerts, C., \& Miranda, D. R. (1995), Performance and burnout in intensive care units. Work Health and Organisations, 9 (4), 513-527.

Kilfedder, C.J ., Power, K. G., \& Wells, T. J. (2001). Burnout in psychiatric nursing. J. Adv. Nurs, 34 (3), 383-396.

Kotter, J. P., \& Schlesinger, L. A. (2008). Choosing strategies for change. Harvard Business Review, 86 (7/8), July-August, 132-139.

Leiter, M. P., \& Maslach, C. (2009). Nurse turnover: the mediating role of burnout. J. Nurs. Manage, 17 (3), 331-339.

Maslach, C. (2003). Job Burnout: New directions in research and intervention. Current Directions in Psychological Science, 12 (5), 189-192. 
Maslach, C. (2006). Understanding job burnout. In: Rossi, A.M., Perrewe, P.L., Sauter, S.L., editors. Stress and Quality of Working Life Current Perspectives in Occupational Health. Greenwich: Information Age Publishing. p37-51.

Maslach, C., \& Leiter, M.P. (2016). Understanding the burnout experience: Recent research and its implications for psychiatry. World Psychiatry, 15(2), 103-111.

Maslach, C., \& Jackson, S. E. (1981). The measurement of experienced burnout. Journal of organizational behavior, 2(2), 99-113.

Moore, J. O. E. (2000), Why is this happening? A causal attribution approach to work exhaustion consequences. Academy of Management Review, 25(2), 335-349.

Najam, U., Ishaque, S., Shoukat, S., Awan, H. M., \& Ansari, N. (2018). Interactive effect of CCM between the relationship of workplace bullying, burnout, and turnover intentions. Cogent Business and Management, 5(1).

Naseer, S., Raja, U., \& Donia, M. (2016). Effect of perceived politics and perceived support on bullying and emotional exhaustion: The moderating role of Type A personality. Journal of Psychology, 150, 606-624.

Naseer, S., \& Khan, M. B. (2015). The Deleterious Effects of Workplace Bullying on Employee's Job Strains in Pakistan. European Journal of Business and Management, 7(4), 180-190.

Puleo, G. (2011). Causes and Maintenance Factors of Employee Burnout during Transformational Organizational Change. Doctoral dissertation. Walden University.

Rabatin, J., Williams, E., Manwell, L. B., Schwartz, M. D., Brown, R. L. B., \& Linzer, M. (2015). Predictors and outcomes of burnout in primary care physicians. J. Prim. Care Comm. Health, 1-3.

Rai, A., \& Agarwal, U. A. (2017). Linking workplace bullying and work engagement: The mediating role of psychological contract violation. South Asian Journal of Human Resources Management, 4, 42-71.

Rafferty, A. E., \& Griffin, M. A. (2006). Perceptions of organizational change: a stress and coping perspective. J. Appl. Psychol, 91 (5), 1154.

Shanafelt, T., Goh, J., \& Sinsky, C. (2017), The business case for investing in physician wellbeing. JAMA Internal Medicine, 177 (12), 1826-1832.

Siegel, P. A., Post, C., Brockner, J., Fishman, A. Y., Garden, C. (2005). The moderating influence of procedural fairness of the relationship between work-life conflict and organizational commitment. Journal of Applied Psychology, 90 (1), 13-24.

Srivastava, S., \& Dey, B. (2019). Workplace bullying and job burnout: A moderated mediation model of emotional intelligence and hardiness. International Journal of Organizational Analysis, 28(1), 183-204.

Wilson, K., \& Baumann, H. (2015). Capturing a more complete view of employees' lives outside of work. The introduction and development of interrole conflict constructs. Personnel Psychology, 68, 235-282.

Wright, T. A., \& Bonett, D. G. (1997). The contribution of burnout to work performance. Organizational Behavior, 18 (5), 491-499.

Wright, T. A., \& Cropanzano, R. (1998). Emotional exhaustion as a predictor of job performance and voluntary turnover. Applied Psychology, 83 (3), 486-493.

Yahaya, A., Ing, T. C., Lee, G. M., Yahaya, N., Boon, Y., Hashim, S., \& Taat, S. (2012). The impact of workplace bullying on work. Archives Des Sciences, 65 (4), 18-28. 
Yeun, Y. R., \& Han, J. W. (2016). Effect of nurses' organizational culture, workplace bullying and work burnout on turnover intention. International Journal of BioScience and BioTechnology, 8(1), 372-380.

Yildiz, S. M. (2015). The Relationship between bullying and burnout: An empirical investigation of Turkish professional football players. Sport, Business and Management: An International Journal, 5, 6-20.10.1108/SBM-09-2012-0034. 